Janusz Degler

\title{
O marginaliach (i nie tylko) Tadeusza Różewicza
}

\begin{abstract}
Degler Janusz, O marginaliach (i nie tylko) Tadeusza Różewicza [On Różewicz's margin notes (and not only)]. „Przestrzenie Teorii” 21. Poznań 2014, Adam Mickiewicz University Press, pp. 11-22. ISBN 978-83-232-2740-3. ISSN 1644-6763.

Tadeusz Różewicz moved from Gliwice to Wrocław in 1968. He lived near South Park for many years and he regularly met there with the author of this article. They talked about many different things and current events, and especially about Stanisław Ignacy Witkiewicz, i.e. more specifically about his service in the tsarist army, the battle that took place near the Stokhid in June 1916 in which he was severely wounded as well as about the causes of his suicide in September 1939. In 2003 Różewicz moved to a house on Promień Street, which is located in a remote area of the city. When he was moving to the new place he came across Witkacy's 1919 treatise titled Nowe formy w malarstwie i wynikające stad nieporozumienia [New Forms in Painting and the Misunderstandings Arising Therefrom], which he had bought in October 1945 at a street stall in Warsaw. After a careful reading of the treatise (as evidenced by numerous underlines in the text), he decided to enroll in the Academy of Fine Arts in Cracow. The quotes that are presented in the article show that Różewicz paid particular attention to Witkacy's main philosophical concepts ("metaphysical anxiety") and statements about the end of metaphysics in the 20th century. Many notes and annotations in the margins, some of which are cited in the present article, are evidence of Witkacy's critical reading of Leon Chwistek's "Wielość rzeczywistości w sztuce" i inne szkice literackie [The Multiplicity of Realities in Art and Other Literary Sketches]. In 1975 Anna Micińska published, based on a manuscript that had been discovered, the sociocultural study Niemyte dusze [Unwashed Souls] which Witkacy wrote in 1936 but which he did not manage to publish. Różewicz regarded this study as one of Witkacy's most interesting works because it showed a whole different side of the artist - a citizen who was concerned about the condition of Polish society and the Polish state.
\end{abstract}

\section{Park Południowy}

Było to chyba w kwietniu 2003 roku. Spotkaliśmy się rano w parku Południowym i odbyliśmy tradycyjny spacer wokół stawu. Potem usiedliśmy na tej co zawsze ławce, skąd roztacza się widok na staw i porośniętą wysepkę przy prawym brzegu. Milczeliśmy długą chwilę. Niespodziewanie Tadeusz Różewicz wstał, podał mi rękę i powiedział, że to nasze ostatnie spotkanie w parku. „Przeprowadzam się na Biskupin”. Zanim zdążyłem cokolwiek odpowiedzieć, ruszył w stronę ulicy Januszowickiej.

Spotykaliśmy się $\mathrm{w}$ tym pięknym parku prawie trzydzieści lat, a od roku 1990, kiedy ponownie zamieszkałem w domu moich rodziców przy ulicy Turniejowej, regularnie przychodziłem tu na spacer z psem. Nie musieliśmy się umawiać, ponieważ było to ulubione miejsce porannych 
przechadzek Tadeusza Różewicza, któremu poświęcił utwór zatytułowany wiersz:

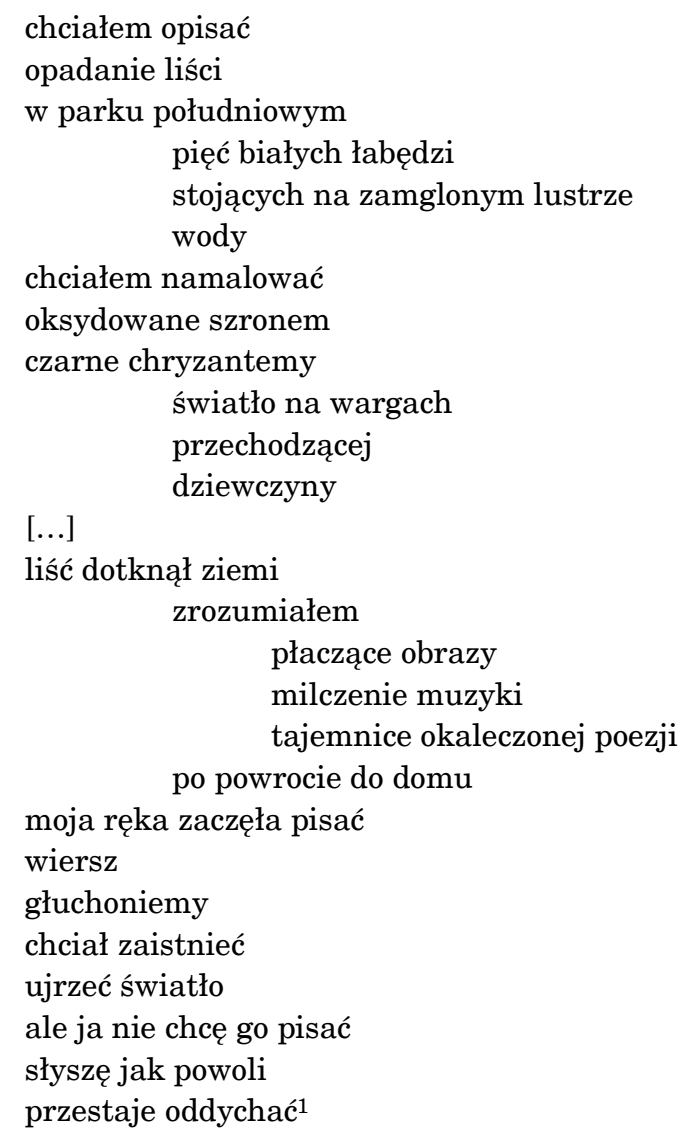

Oczywiście każde spotkanie było okazją do rozmów.

W parku Południowym - pisze Tadeusz Różewicz - rozmawialiśmy prawie zawsze o Witkacym i najnowszych odkryciach witkacologów. [...] Mówiliśmy o malarstwie, o fotografii, samobójstwie i fikcyjnym pogrzebie Witkacego... Mówiliśmy o żonie Witkacego, którą spotykałem w Domu Literatów przy ulicy Krupniczej 22 w Krakowie. Wdowa po Witkacym wydawała mi się piękna, elegancka... pamiętam niezwykłe oczy... [...] Rozmowy o Witkacym dotyczyły jego życia, tzw. tajemnych fragmentów tego niezwykłego życia. Nie mówiliśmy o sztukach, powieściach, szkicach filozoficznych..., bo te rzeczy obaj znamy. Ja pytałem Profesora, co on myśli o samobójstwie Witkacego. Wersja „popularna” mówiła, że Witkacy popełnił samobójstwo ze strachu przed bolszewikami, komunizmem,

1 T. Różewicz, Na powierzchni poematu i w środku. Nowy wybór wierszy, Warszawa 1983; przedruk w: tenże, Utwory zebrane. Poezja 3, Wrocław 2006, s. 240-241. 
„wielkim bratem”..., ale czego naprawdę bał się Witkacy, nikt nie wie... Moim skromnym zdaniem bał się siebie, życia, wojny, niewygód... Albo był zmęczony i chciał zasnąć bez przebudzenia. Czego bał się Witkacy? Zostały jakieś strzępy informacji, że bardzo się bał wojny i śmierci... Pytałem Profesora, co myśli o Witkacym „politruku” Czerwonej Armii, albo czy Witkacy nie umierał ze strachu na froncie. Jakich poznał malarzy w St. Petersburgu?... Opowiadałem Profesorowi, jak na ruinach Warszawy wczesną jesienią 1945 roku kupiłem książki Witkacego. Dla mnie było to „wykopalisko”, jak odkrycie Troi... Dopytywałem się o komediowy „pogrzeb” Witkacego w Zakopanem, kto tam kogo pochował. Mówiłem o planowanych sztukach, związanych ze śmiercią (pogrzebem) Witkacego. O tych sprawach rozmawiałem też z Jerzym Jarockim².

\section{Odkrycie Troi}

Mieszkanie w starej wielopiętrowej kamienicy przy ul. Januszowickiej 13 było drugim mieszkaniem Różewicza po jego przenosinach w 1968 roku z Gliwic do Wrocławia.

Pierwsze mieściło się przy ruchliwej ulicy Glinianej 55, którą przetaczały się ze zgrzytem tramwaje, a po drugiej stronie domu znajdowało się hałaśliwe boisko szkolne. Januszowicka zaś to niewielka wąska uliczka w południowej dzielnicy Wrocławia, na której hałas czynią jedynie śmieciarki. Do parku Południowego Różewicz miał około 400 metrów. A jednak w nowym miejscu całkowitego spokoju nie znalazł. Często skarżył się na dokuczliwych sąsiadów, którzy nieustannie coś remontowali, przerabiali, adaptowali. W roku 2003 jako honorowy obywatel Wrocławia otrzymał od władz domek z ogródkiem na drugim końcu miasta.

Po kilku tygodniach zatelefonował i zaprosił na ulicę Promień, taką bowiem nazwę nosi ulica, przy której znajduje się ów domek i która podobnie jak Januszowicka jest niewielka i spokojna. Najpierw obeszliśmy cały ogródek, w którym Pani Wiesława zdołała już urządzić rabatkę z kwiatami, potem obejrzałem pokój do pracy i wreszcie usiedliśmy przy stole w dużym pokoju rozświetlonym promieniami zachodzącego słońca. Pan Tadeusz trzymał na kolanach książkę. Zaczął mówić o trudach przeprowadzki, która jednak dla kogoś, kto ma wielki, gromadzony latami księgozbiór, staje się ekscytującą przygodą. To niemal jak praca archeologa. Odkrywa się kolejne warstwy i znajduje zapomniane skarby. Im głębiej ukryte, tym cenniejsze. Oto jeden z nich. Położył na stole książkę. Serce żywiej mi zabiło. Były to Nowe formy $w$ malarstwie $i$ wynikajace

2 T. Różewicz, Spotkania, [w:] Między teatrem a literaturą. Księga ofiarowana Profesorowi Januszowi Deglerowi w 65. rocznicę urodzin, red. A. Juzwenko, J. Miodek, Wrocław 2004, s. 13. 
stad nieporozumienia Witkiewicza, wydane w roku 1919. „Odnalazłem teraz wiele książek, o których zupełnie zapomniałem, o tej pamiętałem, ale myślałem, że zaginęła podczas kolejnych przeprowadzek. Kupiłem ją na straganie w bramie zburzonego domu na ulicy Wilczej”3. Taki był początek długiej opowieści o tym, jak po wyjściu z partyzantki znalazł się w październiku 1945 roku w Warszawie, nie bardzo jeszcze wiedząc, co ze sobą zrobić. W jakimś gościnnym pokoiku zaczął czytać, zaznaczając ołówkiem niektóre fragmenty lub podkreślając poszczególne zdania. „Miałem wtedy nabożny stosunek do tej książki, pierwszej, którą kupiłem po kilkuletniej przerwie. Później na pewno upstrzyłbym ją różnymi uwagami, co robił też Witkacy na marginesach czytanych książek"4. Pan Tadeusz wstał i poszedł do swego pokoju, by po chwili wrócić z niewielkim tomikiem. Były to Narodziny tragedii Nietzschego w przekładzie Leopolda Staffa z 1907 roku. Otworzył na stronie tytułowej z zaznaczonymi numerami stron i adnotacją: odnalazłem przy przeprowadzce. Wrocław 2. VIII 2004. „Niech Pan weźmie obie i może coś o tym napisze, ale Witkacego proszę oddać, bo to moja Troja. Ucieszyłem się z jej odkrycia”. I dodał, że w takim momencie łatwo wyobrazić sobie radość Schliemanna, gdy dokopał się do murów Troi, które uznał za niezbity dowód prawdziwości mitycznych dziejów opowiedzianych w Iliadzie. Rozmawialiśmy o tym przez kilka minut i Pan Tadeusz powrócił do przerwanego wątku opowieści o swoich pierwszych tygodniach normalnego życia. Lektura Witkacego utwierdziła go w postanowieniu podjęcia studiów. Pojechał do Krakowa, gdzie został przyjęty do Akademii Sztuk Pięknych.

\section{Niepokój metafizyczny}

Nowe formy $w$ malarstwie to traktat, który Witkacy zaczął pisać w Rosji i ukończył po powrocie do kraju w listopadzie 1918 roku. Wyłożył w nim nie tylko swoje poglądy na sztukę, ale także na przyszłość ludzkości i grożące jej niebezpieczeństwa. Egzemplarz Różewicza przetrwał w dobrym stanie. Na stronie tytułowej widnieje adnotacja: zakupione jesienia 1945 r. na ulicy $w$ Warszawie, a na prawym marginesie pionowy rząd notatek:

3 W stosie książek „wygrzebał” także Pożegnanie jesieni i Nienasycenie - zob. T. Różewicz, Wbrew sobie. Rozmowy z Tadeuszem Różewiczem, oprac. J. Stolarczyk, Wrocław 2011, s. 225.

4 W roku 2004 na wystawie w Centrum Sztuki Współczesnej w Zamku Ujazdowskim pokazano kilkanaście książek filozoficznych z notatkami Witkacego na ich marginesach. Różewicza zachwycił katalog wystawy, który mu pokazałem (S.I. Witkiewicz, Stanisław Ignacy Witkiewicz. Marginalia filozoficzne, teksty B. Michalski, P. Polit, Warszawa 2004). 
str. 154 Bergson / metafizyka / skonała str. 145, VI 148 / samobójstwo filozofii / 181 czarny / obraz byka / str. 174/ 176 / 177/ teatr / 178 / 179.

Przejrzałem dokładnie, strona po stronie, cały tekst, podkreślając w swoim egzemplarzu Nowych form $w$ malarstwie te fragmenty, które Różewicz zaznaczył ołówkiem lub niebieską kredką5. Wszystkie wpisałem do komputera. Gdy się je czyta, łatwo dostrzec, że jego uwagę zwróciły te sformułowania, które zawierają kluczowe pojęcia filozofii, historiozofii i estetyki Witkiewicza. Oto kilka z nich:

To poczucie jedności naszego „ja”, bezpośrednio dane, które nazwiemy jakościa jedności i które musimy uznać za istniejace zawsze $w$ „tle zmięszanym” innych jakości, leży u podstawy uczucia niepokoju metafizycznego, którego przejawami u wyższych Istnień Poszczególnych jest religia, filozofia i sztuka, majace wspólne źródto, ale zróżniczkowane w ciągu spotecznego rozwoju” (s. 8).

Sztuka, jak to postaramy się wykazać, $w$ istocie swojej, nie $w$ nieistotnych jej elementach, jest wyrazem tej jedności każdego Istnienia Poszczególnego, w której przeciwstawia się ono wszystkiemu temu, co nim nie jest, catości Istnienia (s. 9).

Żyjemy bowiem $w$ epoce straszliwej, jakiej nie znała dotad historia ludzkości, a tak zamaskowanej pewnymi ideami, że człowiek dzisiejszy nie zna siebie, $w$ kłamstwie się rodzi, żyje $i$ umiera $i$ nie zna głębi swojego upadku (s. 37).

Sztuka jest sfera, w której kłamstwo nie może pod żadnym warunkiem wydać pozytywnych rezultatów (s. 40).

$W$ miare tego jak życie staje się $w$ rozwoju społecznym coraz wygodniejsze, pewniejsze $w$ swoich zarysach, bardziej automatyczne $i$ mechaniczne $w$ swoich funkcjach, coraz mniej jest miejsca $w$ duszy ludzkiej na metafizyczny niepokój (s. 148).

Metafizyka skonała 6 , ale trzeba urzadzić oględziny trupa, sporzadzić akt zejścia $i$ ogtosić to tlumom według wszelkich form i ze wszystkimi szykanami, aby idealni członkowie społeczeństwa, spełniajac automatycznie funkcje, mające uszczęśliwić ludzkość, mogli się powołać na jakiś auto-

${ }^{5}$ Są to strony: $8,9,10,11,13,14,17,31,33,35,36,40,43,51,57,67,124,137,141$, 147, 148, 153, 154, 162, 164, 168, 171, 175, 176, 177, 179, 180, 182, 183, $186,187$.

${ }_{6}$ Od tych słów zaczyna się wiersz Ślepa kiszka z tomu Zielona róża (1961):

Metafizyka skonała powiedział Witkacy

i odszedł

w nic 
rytet, gdy kto im zrobi zarzut, że za mało zagtębiaja się $w$ metafizyczna Tajemnice Istnienia (s. 153).

Tworzenie sztucznych, matych tajemnic, jest symptomem zaniku metafizycznego niepokoju (s. 164).

Metafizyka skończyła swoje istnienie stosunkowo dość pięknie przez powolne samobójstwo, dokonane w ciągu wieków w osobach jej najgodniejszych przedstawicieli. Samobójstwo mówimy dlatego, że nie sq nawet godni imienia morderców filozofowie, pastwiący się już nad trupem. Gorszy nieco koniec czeka Sztukę (s. 165).

Przepisane cytaty zajęły jedenaście stron. Sporządziłem wydruk i wraz z książką oddałem Różewiczowi przy następnym spotkaniu. Przeczytał od razu, komentując krótko niektóre fragmenty, a na koniec stwierdził, że układają się one w pewną całość, tworząc zwięzłe résumé wywodów autora. To, że Witkacy przywiązywał tak wielkie znaczenie do niepokoju metafizycznego ${ }^{7}$ jako źródła twórczości i zarazem warunku właściwego odbioru dzieła sztuki w Czystej Formie, musiało go poróżnić z całą awangardą, której „pachniało” to Młodą Polską. Może dlatego dodałem - Nowe formy przemilczano. Nie ukazała się ani jedna recenzja, a spór między Witkacym a Chwistkiem właśnie w tej sprawie doprowadził do rozpadu grupy formistów. „Ale oni pokłócili się wcześniej z innego powodu. Wiem coś o tym od żony Chwistka, którą poznałem wkrótce po przyjeździe do Krakowa”. Sugestywnie opisał urodę pani Olgi, ujmujący sposób bycia i inteligencję („bądź co bądź siostra profesora Steinhausa!”) i zakończył krótko: „Witkacy miał kompleks Chwistka-uczonego, a Chwistek kompleks Witkacego-artysty”.

\section{Wielość rzeczywistości}

Różewicz wielekroć zapewniał, że gdy poczuje się na siłach, zgodzi się, abym przywiózł go do parku Południowego i znowu odbędziemy spacer wokół stawu i do pomnika Chopina. Niestety, uniemożliwiły to kłopoty ze zdrowiem. Pozostały sporadyczne wizyty na ulicy Promień i telefony. Nieraz zaskakujące. Jak choćby ten 24 stycznia 2006 roku, który zaczą się od pytania, czy w Dniu Dziadka dostałem prezenty od moich wnucząt. Po odpowiedzi, że tylko telefonowały z życzeniami, usłyszałem: „To dostanie pan ode mnie. Proszę przyjechać”. Wsiadłem do samochodu

7 Stanowczo ostrzegł mnie, abym jednak nie wiązał tytułu tomu Niepokój (1947) z Witkacowskim pojęciem niepokoju metafizycznego. 
i w żółwim tempie po oblodzonej jezdni dobrnąłem na ulicę Promień. Gdy usiedliśmy przy stole, zobaczyłem leżącą na nim książkę. Był to dobrze znany mi tom „Wielość rzeczywistości $w$ sztuce” $i$ inne szkice Leona Chwistka, wydany przez Karola Estreichera w 1960 roku. Wyraźnie ożywiony Pan Tadeusz powiedział, że właśnie odkrył go podczas dalszych prac archeologicznych w księgozbiorze, zaczął czytać, znajdując $\mathrm{w}$ nim swoje liczne notatki na marginesach poczynione dawno temu i uradowany postanowił telefonicznie powiadomić o tym przyjaciela Mieczysława Porębskiego. Następnie otworzył egzemplarz na stronie przedtytułowej i ołówkiem starannie wpisał dedykację - najosobliwszą i najcenniejszą, jaką posiadam:

22 stycznia 19 (znów zaczq̨łem pisać 19... a przecież to rok 2006) zadzwoniłem do Mietka - który siedzi u Córki, pod Warszawa - powiedziałem mu, że po 25letniej przerwie czytam Chwistka... a Mietek mi na to, że właśnie siedzi nad Chwistkiem (logika?) pamiętam wdowe po Chwistku i jego córkę (pania Dawidowicz) obie Panie jadały na Krupniczej 22 obiady więc je często spotykatem - byty to wspaniałe (wielkie damy - Baby Damy - urodziwe niezwykte) (Witkacy... no, właśnie.) Dziś jest - 20 stopni „Dzień dziadka” (idioci wczoraj Dzień babci-w TV tańczace babunie).

Marginaliów jest dużo i różnego rodzaju. Oprócz zaznaczonych kółkiem fragmentów są liczne podkreślenia, dopiski i niekiedy żartobliwe uwagi. Wyraźnie irytowało go często pojawiające się słowo „natura”, co na stronie 130 skomentował: „natura” - ch. nie mówi - co to jest?! czy tyłek baby czy róża? itd. Nieco dalej (s. 139) znajdujemy wierszyk:

ale „natura” jest mysz i góra

stoń i mucha, jabtko i chwistek

albo noga chwistka $i$ koński ogon

Przy zdaniu: „Doświadczenie nauczyło nas tej wielkiej prawdy, że natura jest czymś, co my na swój sposób tworzymy, i że zależna jest od naszych zdolności twórczych" (s. 139) dopisał: nie nie. Nad tytułem artykułu Tytus Czyżewski a kryzys formizmu widnieje „apel” do autora: Chwistek! Niech Pan się opamięta (s. 107), a przy dwuwierszu Czyżewskiego: „Wdziej ciepłe astrachany/Termometr wciąż opada..." uwaga: śmieszne (s. 106). Dobitniej stosunek do jego poezji wyraził zdaniem: ale to śmieszne, kiepskie wiersze (s. 105). Zdanie: „W naszych oczach dorwała się do władzy ideologia zakutych łbów podoficerów i deprawowanych kucharek i niweczy kulturę zdobytą przez naród niemiecki w ciągu wiekowych wysiłków" opatrzył pytaniem: dlaczego kucharek? Cytat z Pana Tadeusza: „...Żeby 
też wzięły wieśniaczki do ręki/Te księgi proste jako ich piosenki” sprowokował pytanie: jakie sa „wieśniaczki” teraz?!

Najwięcej podkreśleń zawiera tekst Teatr przyszłości z 1922 roku. Pogrubioną linią zaznaczony został fragment:

W dobrym dramacie poszczególne sceny powinny być zbudowane w ten sposób, żeby ich wartość estetyczna nie zależała od znajomości scen pozostałych. Pomimo to powinny tworzyć jednolitą całość. Usunięcie jedności czasu i miejsca było pierwszym krokiem w tym kierunku. Sądzę, że należy usunąć jedność osób i akcji. Przede wszystkim należy usunąć bohatera, względnie parę bohaterów. Ta sama osobistość plącząca się po scenie od początku do końca i narzucająca nam swoje osobiste sprawy z całą bezwzględnością jest o wiele zjadliwsza od tych jegomościów, którzy na wizycie pragną opowiadaniem anegdot lub własnych przeżyć trzymać na uwięzi uwagę wszystkich obecnych. Różnica jest tylko ta, że z teatru nie zawsze łatwo wyjść w czasie przedstawienia, zwłaszcza jeśli się ma krzesło środkowe (s. 178).

Różewicz zamieścił tu znamienne wyznanie: pisałem Kartotekę nie czytajac tego! ciekawe! A na odwrotnej stronie przedtytułowej ilustracji, nawiązując do ostatniego zdania powyższego fragmentu, zanotował: temat do opracowania: trudna sztuka wychodzenia z teatru (opery? koncertu? itd.) np. jeśli sie jest zaproszonym przez aktora, dyrektora itp. $i$ siedzi się $w$ pierwszym rzędzie. Niestety, tematu tego Różewicz nie opracował. Szkoda. Poradnik o sztuce wychodzenia z teatru bardzo by się przydał...

\section{Czego bał się Witkacy?}

To pytanie często powracało w naszych rozmowach. Albo w kontekście doświadczeń partyzanckich Różewicza, albo w związku z aktualnymi wydarzeniami. Interesowało go wszystko, co dotyczyło służby Witkacego w Lejb-gwardii Pawłowskiego Pułku, wokół której powstało wiele legend, m.in. także ta, że był „czerwonym komisarzem”. Lata 1914-1918 długo pozostawały białą plamą w jego biografii. Dopiero w połowie lat osiemdziesiątych na fali pierestrojki Gorbaczowa można było je usunąć, dzięki dostępowi do dokumentów znajdujących się w moskiewskim Archiwum Wojskowo-Historycznym. Na podstawie pierwszych publikacji, wykorzystujących te materiały ${ }^{8}$, sporządziłem kalendarium pobytu Witkacego w Rosji, które wręczyłem Różewiczowi. Długo rozmawialiśmy o bitwie, która rozegrała się w lipcu 1916 nad rzeką Stochod. Witkacy, prowadząc

${ }^{8}$ K. Dubiński, Moskiewskie witkacjana, „Sztuka” 1988, nr 5-6, s. 102-103. 
swoją kompanię do ataku, został ciężko ranny. Nieraz Różewicz opowiadał mi o przeżyciach, jakich się doznaje, gdy pada rozkaz „do ataku”. Lęk przed śmiercią sprawia, że nie sposób zapanować nad reakcjami ciała i odruchami fizjologicznymi. Czy Witkacy się bał? Być może zanotował swoje doznania w dzienniku, który prowadził w czasie pobytu w Rosji i który zniszczył po przyjeździe do kraju. Wiadomo tylko, że niechętnie powracał wspomnieniami do tamtego okresu, ale niekiedy przyjaciołom opisywał „straszliwe, wprost niesamowite paroksyzmy strachu, które przeżywał nieraz pod ogniem pierwszej linii okopów, albo gdy na pół przytomny ze zdenerwowania, roztrzęsiony jak galareta, prowadził swych ludzi do ataku na niemieckie pozycje"9.

Czego bał się we wrześniu 1939 roku? Prawdopodobnie odpowiedzią miała być sztuka, nad którą Różewicz zaczął pracować w 1989 roku. W kwietniu tego roku pochowano uroczyście na starym cmentarzu zakopiańskim szczątki, które delegacja partyjno-rządowa przywiozła z Jezior, gdzie Witkacy popełnił samobójstwo na wiadomość o wkroczeniu armii sowieckiej na ziemie polskie ${ }^{10}$. Zdałem Różewiczowi dokładne sprawozdanie z przebiegu całej uroczystości. Podzieliłem się też wątpliwościami, że chyba nastąpiła tragikomiczna pomyłka i w grobie matki zamiast syna pochowano obcą osobę ${ }^{11}$. Na wykonanych w czasie ekshumacji zdjęciach ma ona pełne uzębienie, a z listów Witkacego do żony wynika, że w roku 1937 nosił już protezy. Potem Różewicz dopytywał się jeszcze o różne szczegóły pogrzebu i po kilku tygodniach zdradził mi pomysł sztuki, której akcja miała się zacząć od homilii ks. Tischnera wygłoszonej podczas mszy w starym kościółku na Pęksowym Brzysku i przemówienia ministra Krawczuka nad trumną sprowadzoną z Jezior. W czasie egzekwii duch Witkacego „materializował się" i powracał pamięcią do sytuacji, kiedy leży na polu bitwy nad Stochodem, przekonany, że niebawem umrze. Przed oczyma staje mu całe życie, także to późniejsze, aż do momentu, gdy wspólnie z towarzysząca mu Czesławą Oknińską postanawiają popełnić samobójstwo. Nie wiem, jak daleko zaawansowana była praca nad sztuką i jaki miał być jej tytuł. Różewicz nie poruszał już tego tematu, mnie pytać nie wypadało. Podobny pomysł wykorzystał w 1995 roku Jerzy Jarocki w spektaklu Grzebanie według własnego scenariusza.

9 J.M. Rytard, Witkacy, czyli O życiu po drugiej stronie rozpaczy, [w:] Stanisław Ignacy Witkiewicz. Człowiek i twórca. Księga pamiątkowa, red. T. Kotarbiński, J.E. Płomieński, Warszawa 1957, s. 281.

10 Oddział AK, do którego należał Różewicz, działał na terenach w pobliżu Jezior.

11 Komisja powołana przez ministra kultury i sztuki Kazimierza Dejmka stwierdziła na podstawie przeprowadzonych w listopadzie 1994 ekspertyz, że były to szczątki młodej kobiety. 


\section{Obywatelska twarz Witkacego}

„Nie mówiliśmy o sztukach, powieściach, szkicach filozoficznych...”. To prawda, ale był jeden wyjątek - Niemyte dusze. Różewicz, który chyba dostał egzemplarz od Micińskiej w 1979 roku, był pod dużym wrażeniem lektury tego „studium psychologicznego nad kompleksem niższości (węzłowskiem upośledzenia) przeprowadzonego metodą Freuda ze szczególnym uwzględnieniem problemów polskich". Nieraz, komentując aktualne wydarzenia, korzystał z określeń Witkacego. Do ulubionych należały „uśmiech kretyna”, „kołpak napuszania”, ,jebał-piesizm” i „przyjemniaczek". Kiedy w roku 1981 wprowadzono kartki na papierosy i alkohol, żartował, że Jaruzelski posłuchał chyba rady autora Niemytych dusz: „Wóda za kartkami - jedyne wyjście - inaczej Polska zginie od niej, a głównie od tabaku"12.

Niemyte dusze ukończył Witkacy w lipcu 1936 roku. Próbował je opublikować, ale rozmowy z wydawcami zakończyły się fiaskiem. Trudno się dziwić. Niemyte dusze to bezlitosny rozrachunek z naszymi przywarami, które choć ukształtowały się w czasach demokracji szlacheckiej, to jednak „trują dziś w nie mniejszym natężeniu niż za czasów saskich, a kto wie, czy nawet w ostatnich latach (trzydziestych) nie potęgują się powoli"13. Długi jest ich rejestr: od poczucia własnej małości rekompensowanej „napuszaniem się do nie osiągniętej realnie wielkości” do braku troski o higienę ciała.

Niemyte dusze po wojnie uznano za zaginione. Szczęśliwie odnalazł się jednak maszynopis i na jego podstawie Anna Micińska przygotowała w 1975 roku pierwsze wydanie. Minęło bez większego echa (ukazały się tylko trzy recenzje), a jeden $\mathrm{z}$ historyków zdeprecjonował ich wartość, uznając, że to „zlepek prymitywnych poglądów o stereotypowym charakterze"14. Dopiero Tadeusz Różewicz upomniał się o ich rzetelną ocenę i należne miejsce w polskiej kulturze. Dobiegał właśnie końca rok 1985, ogłoszony przez UNESCO Światowym Rokiem S.I. Witkiewicza. Teatry zgodnie z poleceniem ministerstwa zapamiętale grały jego sztuki, przez prasę przewaliła się lawina artykułów pełnych banałów i stereotypów, odbyło się kilka wystaw i sesji. Większego pożytku z tego nie było15. Różewicz, który nie znosił wszelkiej celebry i obchodów rocznicowych, opu-

12 S.I. Witkiewicz, Dzieła zebrane, [t. 12:] Narkotyki. Niemyte dusze, oprac. A. Micińska, Warszawa 1993, s. 313.

13 Tamże, s. 239.

${ }^{14}$ M. Król, Polska w twórczości Stanisława Ignacego Witkiewicza, [w:] Studia o Stanisławie Ignacym Witkiewiczu, red. M. Głowiński, J. Sławiński, Wrocław 1972, s. 307.

15 Zob. M. Szpakowska, Heca z Witkacym, „Dialog” 1985, nr 12, s. 87-97. 
blikował w październikowym numerze „Odry” kolejną „kartkę wydartą z dziennika”, poświęconą Niemytym duszom. Warto ją przypomnieć, tym bardziej iż nie straciła na aktualności:

To jedna z najciekawszych książek w całym dorobku Witkacego. Takie rozdziały, jak Atmosfera miast, Lokale publiczne, Uśmiech kretyna, Who is who powinny wejść do wypisów szkolnych dla klas licealnych... natomiast studenci powinni przeczytać Znaczenie indywiduum w rozwoju społecznym i tragedia upośledzonych i Hodowla przyjemniaczków, a także Alkohol i Problem NP (niepalenia)... te „realistyczne” felietony i odczyty pisane i ogłaszane dosłownie w przeddzień wrześniowej katastrofy (roku 1939) pokazują drugą twarz „Witkacego”... może mniej malowniczą, metafizyczną, dziwaczną i ,genialną", ale za to obywatelską, realistyczną, bliską troskom Bolesława Prusa... Tak! tak! To już nie genialne monstrum podawane nam przy każdej okazji w teatrach, to nie katastrofista, ale obywatel zatroskany o naród, państwo... a nawet o rodzimych „kretynów” i „przyjemniaczków”. Sztuki, powieści, szkice filozoficzne i estetyczne (ale przede wszystkim sztuki teatralne) Witkacego przyrządza się tak, jakby jego twórczość skierowana była przeciwko Polsce Ludowej, komunizmowi itd., tymczasem większość jego utworów skierowana była wyraźnie przeciwko rzeczywistości, która go otaczała, przeciwko Polsce „sanacyjnej”. [...] Odgrywał rolę Kasandry... ale zupełnie realistyczny opis wychodka w Zakopanem wyszedł także spod ręki Witkacego. Jest w tym bliższy „małym realistom” niż „wielkim katastrofistom”. [...] Kiedy obchodzimy uroczyście rocznice związane z życiem Witkacego, nie zapominajmy o autorze Niemytych dusz. Trzeba szanować i kochać obie strony tego niezwykłego medalu. Za samą tylko „rozprawkę" Uśmiech kretyna powinny dzieci przyznać Witkacemu order uśmiechu, a jeśli nie dzieci to ich dorośli opiekunowie. [...] Jednym słowem zamiast urządzać konkursy (dla dzieci!!!, młodzieży), poświęcone W. przedrukujmy jego prace: O brudzie, Problem taźni parowej... Włączmy do lektury obowiązkowej (dla starszych klas) Niemyte dusze... będzie to najlepsza forma uczczenia tego wspaniałego artysty i człowieka. Niech w tym świętym „roku Witkacego” stanie się On nie tylko pretekstem popisów intelektualistów, specjalistów witkacologów, reżyserów, ale niech też będzie lekiem przeciw głupocie, bladze, brudowi, nikotynie, pseudoawangardowej sztuce (która zeszła na psy). Kropka ${ }^{16}$.

Apel pozostał bez echa. Niemyte dusze to wciąż najmniej znane dzieło Witkacego. Ich ostatnie wydanie ukazało się 21 lat temu... Opublikowano w tym czasie kilkanaście książek o Witkacym, setki rozpraw, esejów, artykułów, a jednak kim był, najlapidarniej ujął Tadeusz Różewicz:

Witkacy jest serio, nie podlizuje się ani władzy, ani społeczeństwu, ani Kościołowi, ani „ludowi”, ani „arystokracji”. Jaki to inny snardz od tych różnych lizusów, podlizywaczy, wylizywaczy, którzy podlizują się i dygnitarzom, i możnym,

${ }_{16}$ T. Różewicz, Kartki wydarte $z$ dziennika (4), „Odra” 1985, nr 10, s. 31. 
i seniorom, i młodzieży, i dzieciom, i psom, i rodzimym wierzbom, i sosnom itd., itp. nie bał się pisać prosto i zrozumiale (dla pana profesora i prostaczka) np. o smrodzie! ${ }^{17}$.

\section{Ostatnia rozmowa}

Zatelefonował w Wielką Sobotę z życzeniami i podziękowaniem za odbitkę kserograficzną książki Bogdana Zakrzewskiego Spowiednicy Adama Mickiewicza i Aleksandra Fredry, którą mu przesłałem. Od pewnego czasu bowiem tematem naszych rozmów telefonicznych był autor Zemsty. Interesowała Różewicza genealogia Fredrów (nazwisko miało świadczyć o pochodzeniu węgierskim), dopytywał się, czy genialna Zemsta jest nadal w lekturach szkolnych i nakłaniał do przeczytania Trzy po trzy („to książka odpowiednia dla staruchów”). Umówiliśmy się, że przyjadę w piątek po świętach i otrzymam tytułem rekompensaty za ksero tom poezji wydany w Pekinie z dedykacją, abym zaczął się uczyć chińskiego.

Zgodnie $\mathrm{z}$ ostatnią wolą spoczął na cmentarzyku ewangelickim w Karpaczu obok swego przyjaciela Henryka Tomaszewskiego.

17 Tamże, s. 32 . 


\section{Tadeuss Röievior.}

\section{Stanisław lgnacy Witkiewicz.}

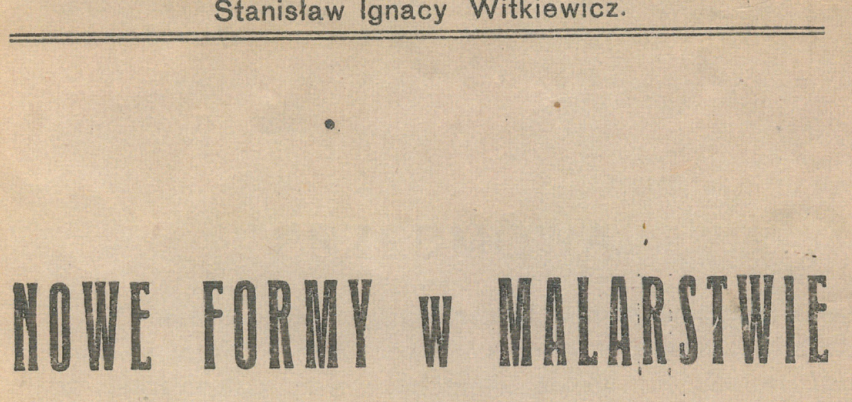

\section{$\div=1 \equiv$ \\ WYNIKAJĄCE STĄD NIEPOROZUMIENIA*}
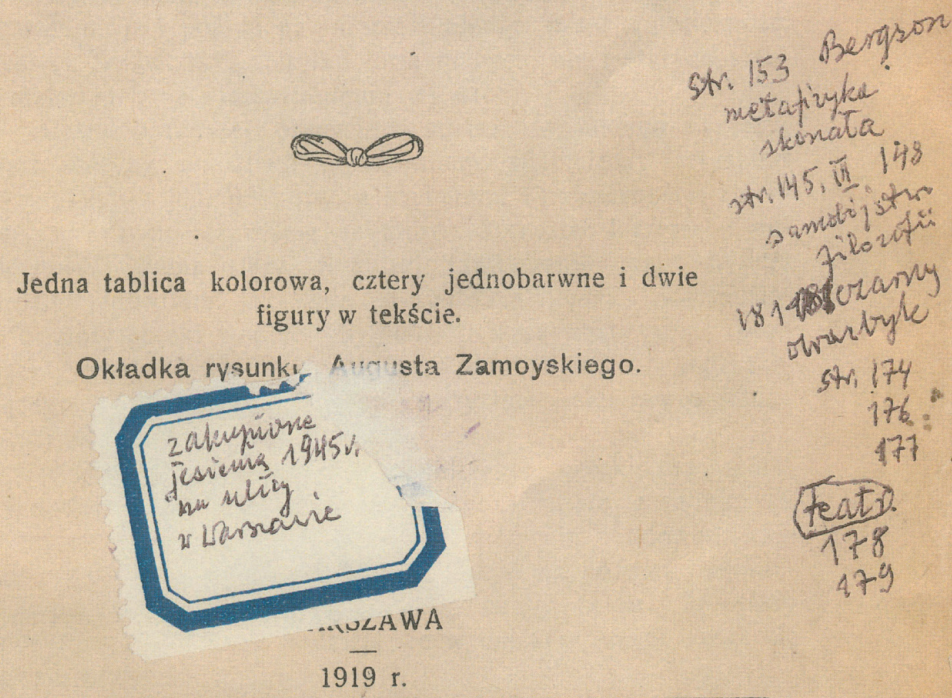

ando $]^{3}$ in

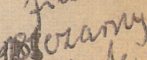
oweriby str. 174 176: 177

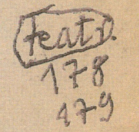

Skład główny w księgarniach Gebethnera i Wolffa--Warszawa-Lublin - Lódź Kraków. G. Gebethner i S-ka.

S.I. Witkiewicz, Nowe formy $w$ malarstwie $i$ wynikajace stąd nieporozumienia, Warszawa 1919 (strona tytułowa z dopiskami Tadeusza Różewicza) 


\section{Fadeusz Roizewicz}

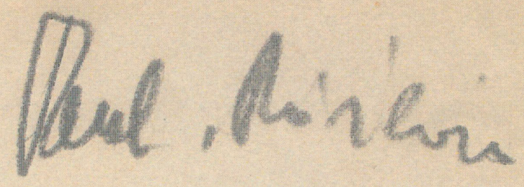

\section{tid 4 in}

colnalarleu.

piry preprowadr Hroctae

2.VIII. 2004

stri 162

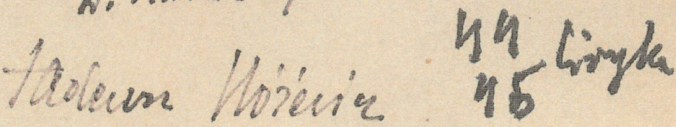

\section{NARODZINY TRAGEDJI}
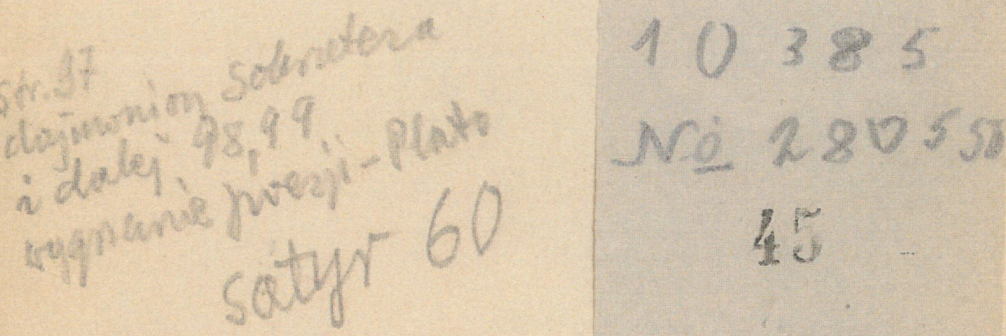

KSIĘGARNIA LOWICKA

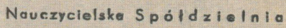

$z$ odpowiedzio'noscia udzialami W kOWICZU

Rynek Kilińskiego Nr. 10

Strona tytułowa Narodzin tragedii Fryderyka Nietzschego w przekładzie Leopolda Staffa, Warszawa 1907 


\section{Wasuosic tadeunn Horkina}

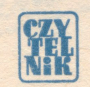

C H W IS TEK

WIELOSC RZECZYWISTOSCI

W SZTUCE

22 styumia 19 (anoir zavrateu hisai 19... a mecies to rok 2006 zadarniteve do wietka - ktong siedri u Córki pod Lamar - pornichiabue mu, 2e 10 25 letrig prervie nytaw chisitler ma thietel mi un to.re wesnie redai nad Christhien (bpileg?)

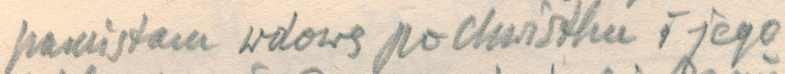
Coily (pawe Davidonir) obie Pavie gadaty ma kmpricie 22 obiady nige je oysto ifuetylealea - ryt

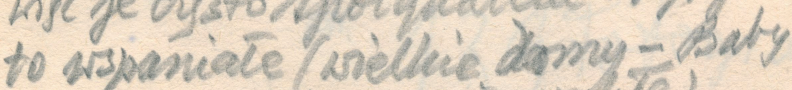

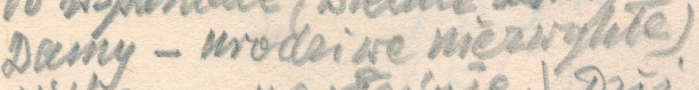
(Withery, no, unashie.) Dris bet

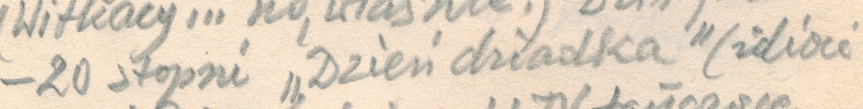

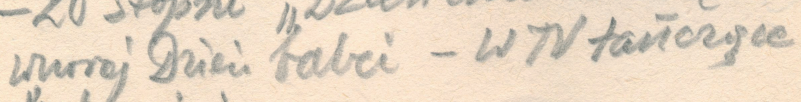
babunie)

Leon Chwistek, „Wielość rzeczywistości w sztuce” i inne szkice literackie, Warszawa 1960.

Dedykacja na stronie tytułowej 


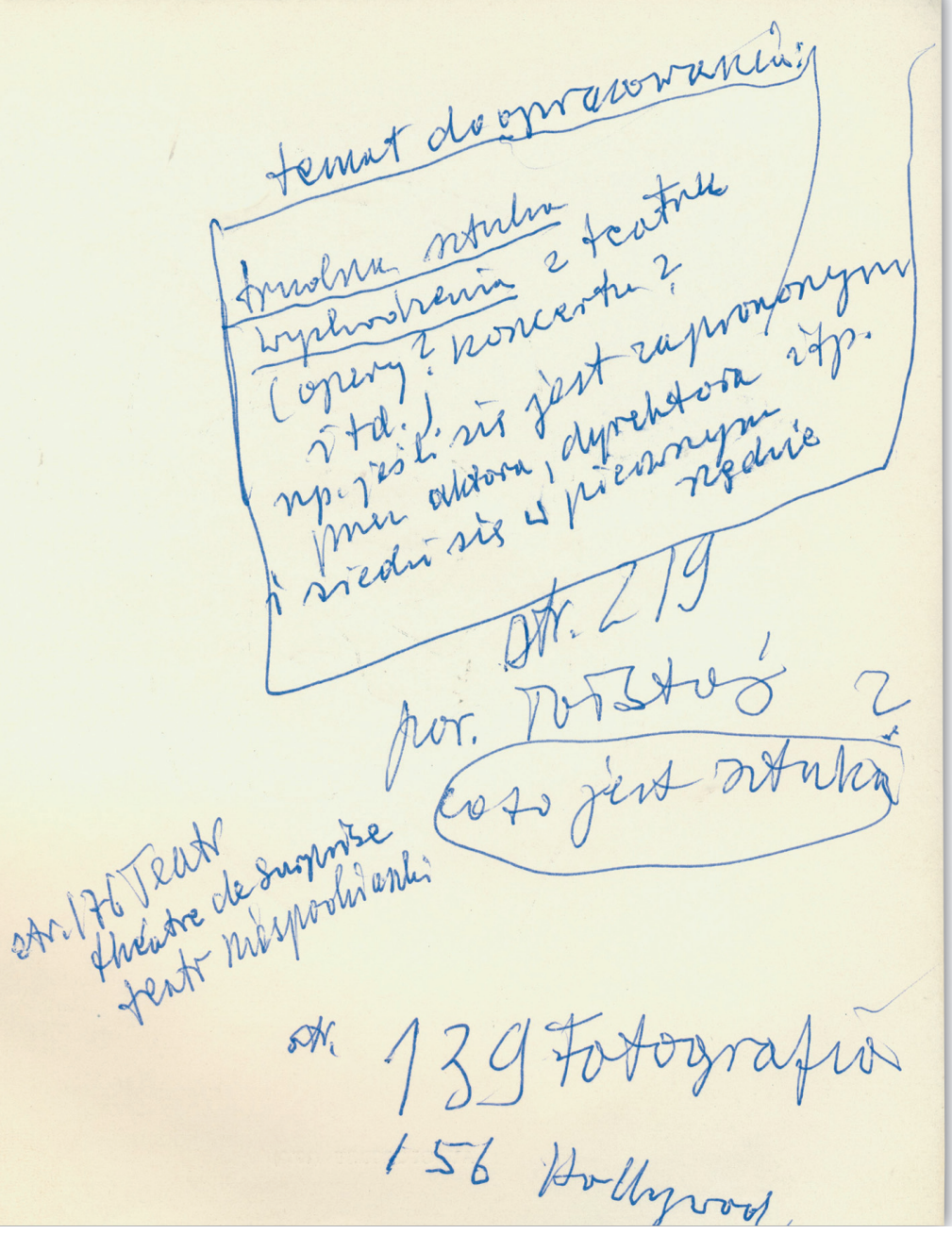

Leon Chwistek, „Wielość rzeczywistości w sztuce” i inne szkice literackie, Warszawa 1960.

Zapiski na odwrotnej stronie ilustracji przedtytułowej 
rytmu, tempo szybsze lub wolne, dźwięk słodki lub chropowaty itp. * Potwierdzenie tych zasad znajdujemy u wielkich poetów wszystkich czasów, że tylko wymienię Danta i Słowackiego. Niedocenienie tychże zasad uczyniło wiele rzekomych dzieł sztuki pamiętnikami bitew, podróży lub tęsknot miłosnych, jeśli nie zgoła wykładami mistycznych doktryn.

Nieświadoma tendencja poezji do opanowania treści przy pomocy formy rozwinęła się z biegiem lat w żywiołowy, celowy wysiłek twórczych jednostek wszystkich krajów i ras. Przyczyną tego faktu jest niewątpliwie zaostrzenie kryteriów pojęciowych we wszystkich dziedzinach myślenia. Dziś już nikt nie chce szukać $w$ poezji pociechy $w$ utrapieniach ani wzmocnienia animuszu, ani potwierdzenia dumy narodowej, ani zabawy, ani nauki, a jeśli nawet przyjdzie jeszcze komuś coś takiego na myśl, to rychło zmieni zdanie, mając do dyspozycji znacznie silniejsze środki prowadzące do tych samych celów. $\mathrm{Ci}_{1}$ którzy pragną poezji naprawdę, wiedzą, że znaleźć w niej można jedną tylko wartość wielką i jedno tylko uczucie godne zaspokojenia, a mianowicie: doskonałą formę i upojenie się tą formą. Dążenie do poezji pojętej w ten włąśnie sposób nazywamy formizmem w poezji. híe víe?

Podobny proces-dokonuje-się- sztukach plastycznych. Zarówno malarz jak rzeźbiarz muszą się liczyć z tym faktem, że formy, które tworzą, mają z natury dwoisty charakter, są bowiem nie tylko same przez się przedmiotami otaczającego nas świata, ale zarazem obrazami innych przedmiotów, które odnajdujemy w nich niezależnie od wszelkiej teorii. Otóż w życiu praktycznym przyzwyczajeni jesteśmy uważać przedmioty rzeczywiste za znaki orientacyjne i w wyjątkowych tylko razach dochodzimy do tego, żeby zdać sobie sprawę $\mathrm{z}$ ich formy: Zadaniem artysty jest zmuszenie widza do odwrócenia powyż-

\footnotetext{
- Por. np. dwuwiersz Czyżewskiego: ${ }_{1}$ Wdziej ciepłe astrachany 7) Termometr wciąż opada."

konivine
}

Leon Chwistek, „Wielość rzeczywistości $w$ sztuce” $i$ inne szkice literackie, Warszawa 1960.

Marginalia na stronie artykułu Formizm 
Rouault, wyrzekli się jawnie wielkiej tradycji naturalizmu i rzucili się na sztukę wyobrażeniową.

Naturalizm został skazany na wegetację i niezaszczytną rolę ośrodka mało ambitnych i tępych pompierów. Pozostała mu tylko dziedzina deformacji, obliczonej na spotęgowanie realistycznego wrażenia, ta właśnie, która reprezentuje Soutine. Wyraźnie mơwię tu o deformacji, w przeciwieństwie, do Cézanne'a i kubistów, gdzie terminu tego, skutkiem odmiennych zupełnie kryteriów tworzenia, żadną miarą z sensem użyć nie można. Droga deformacji ekspresjonistycznej-to już tylko wąska ścieżyna, która pozostała naturalizmowi z jego olbrzymiego zapasu możliwości. Może być, że malarstwo wyobrażeniowe skrystalizuje kiedyś nowe kategorie formowania, w imię których zrodzi się nowy gatunek naturalizmu. To jest sprawa przyszłości. W tej chwili naturalizm jest w impasie, w tej chwi-

li głośna jest sztuka wyobrażeniowa.

\section{stion i mucha lest mysz i góra allio mocha, jabito in ichiriteh \\ abo noga christea i kon'she ozon}

Krótki przegląd historii naturalizmu, jaki tu przedstawiłem, ma na celu udowodnienie tezy, że nie ma czegoś takiego nieruchomego i czekającego na zbadanie, jak natura. Tym samym naczelna zasada naturalizmu, według której sztuka powinna rozwijać się przez coraz to głębsze poznawanie natury, okazuje się fałszywa.

Doświadczenie nauczyło nas tej wielkiej prawdy, że natura jest czymś, co my na swój sposób tworzymy, i że zależna jest od naszych zdolności twórczych. Doświadczenie nauczyło także, że nawet tak prosta stosunkowo sztuka, jak fotografia, nie daje nam określonej jednolicie natury. Mamy fotografię ściśle naturalistyczną, impres jonistyczną i ekspresjonistyczną. Mamy tyle gatunków naturalizmu fotograficznego, ile ich jest w naturalizmie malarskim.

Jeśli tedy chcemy żądnemu wiedzy uczniowi wskazać drogę

Leon Chwistek, „Wielość rzeczywistości w sztuce” $i$ inne szkice literackie, Warszawa 1960, s. 139.

Dopiski na stronie artykułu Tragedia naturalizmu 


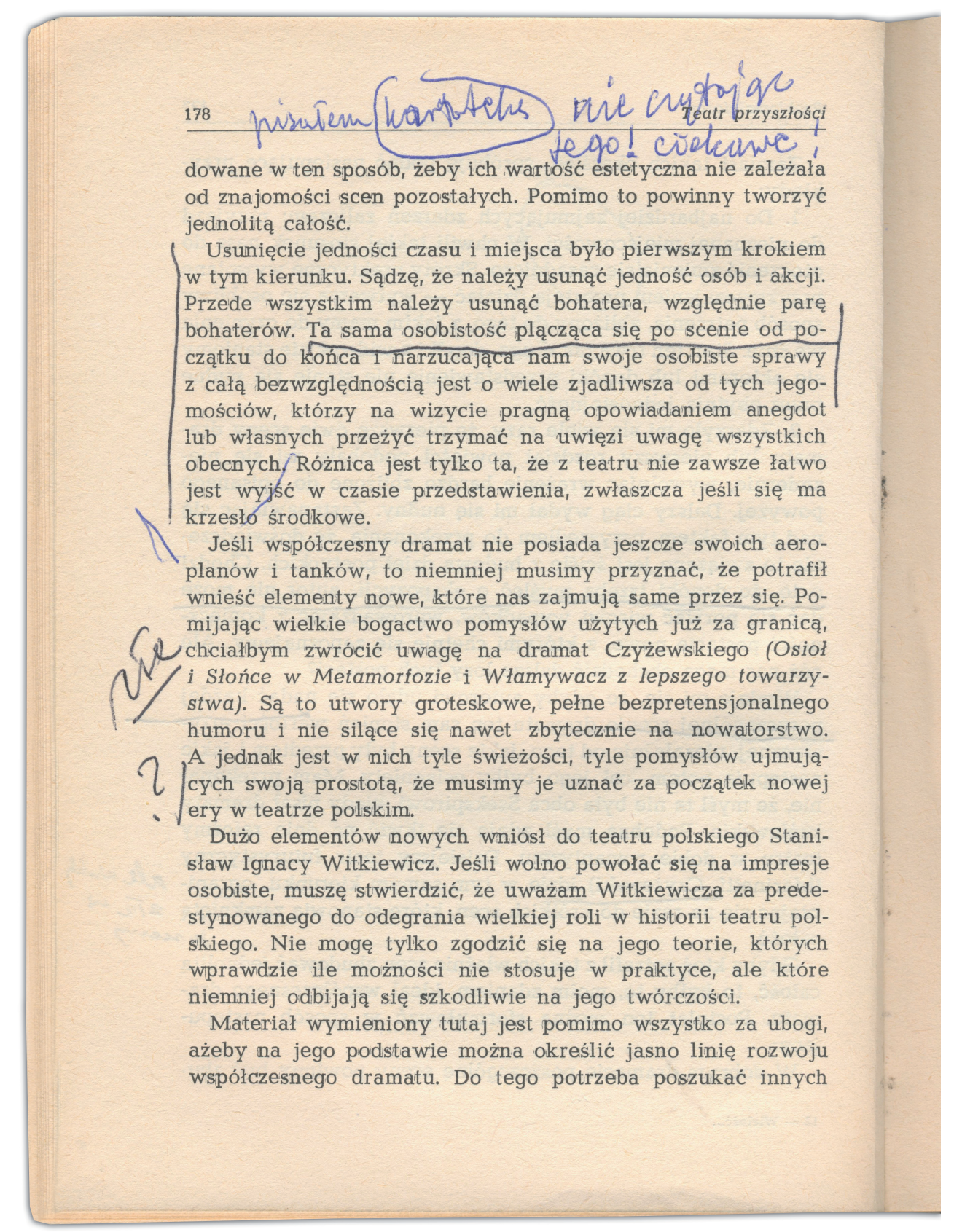

Leon Chwistek, „Wielość rzeczywistości w sztuce” $i$ inne szkice literackie, Warszawa 1960.

Dopiski na stronie artykułu Teatr przyszłości 


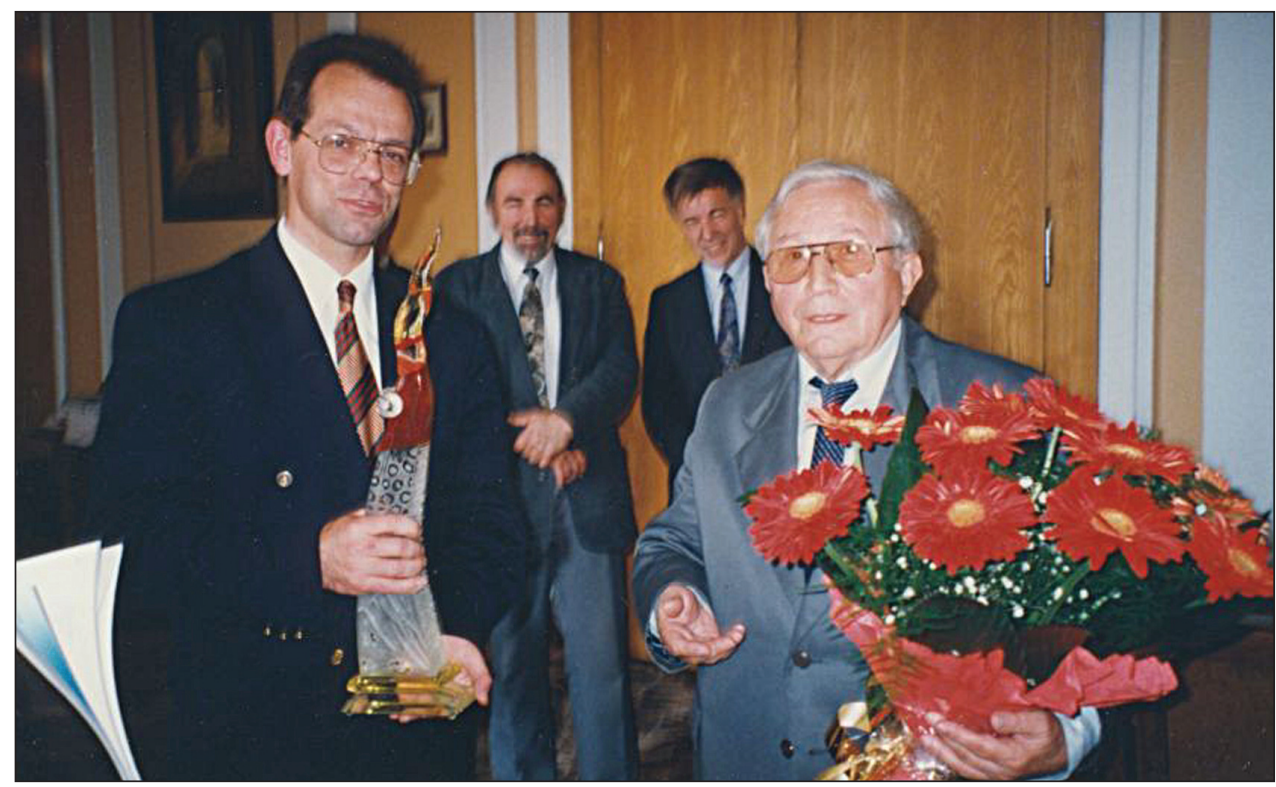

Uroczystość jubileuszu 75-lecia Tadeusza Różewicza

w gabinecie wojewody prof. Janusza Zaleskiego 9 października 1996 roku. Z tyłu Janusz Degler i Jan Miodek

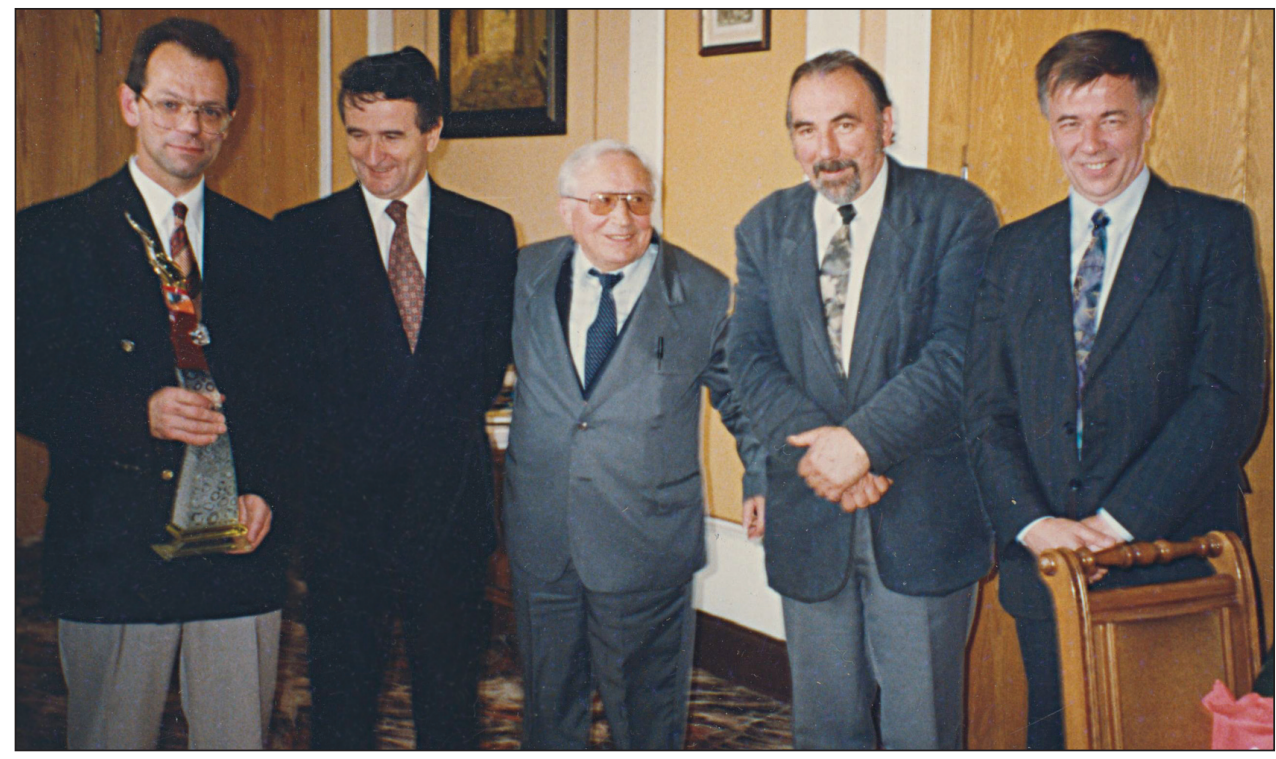

Uroczystość jubileuszu 75-lecia Tadeusza Różewicza w gabinecie wojewody prof. Janusza Zaleskiego. Od lewej: Janusz Zaleski, Leon Kieres, Tadeusz Różewicz, Janusz Degler, Jan Miodek 

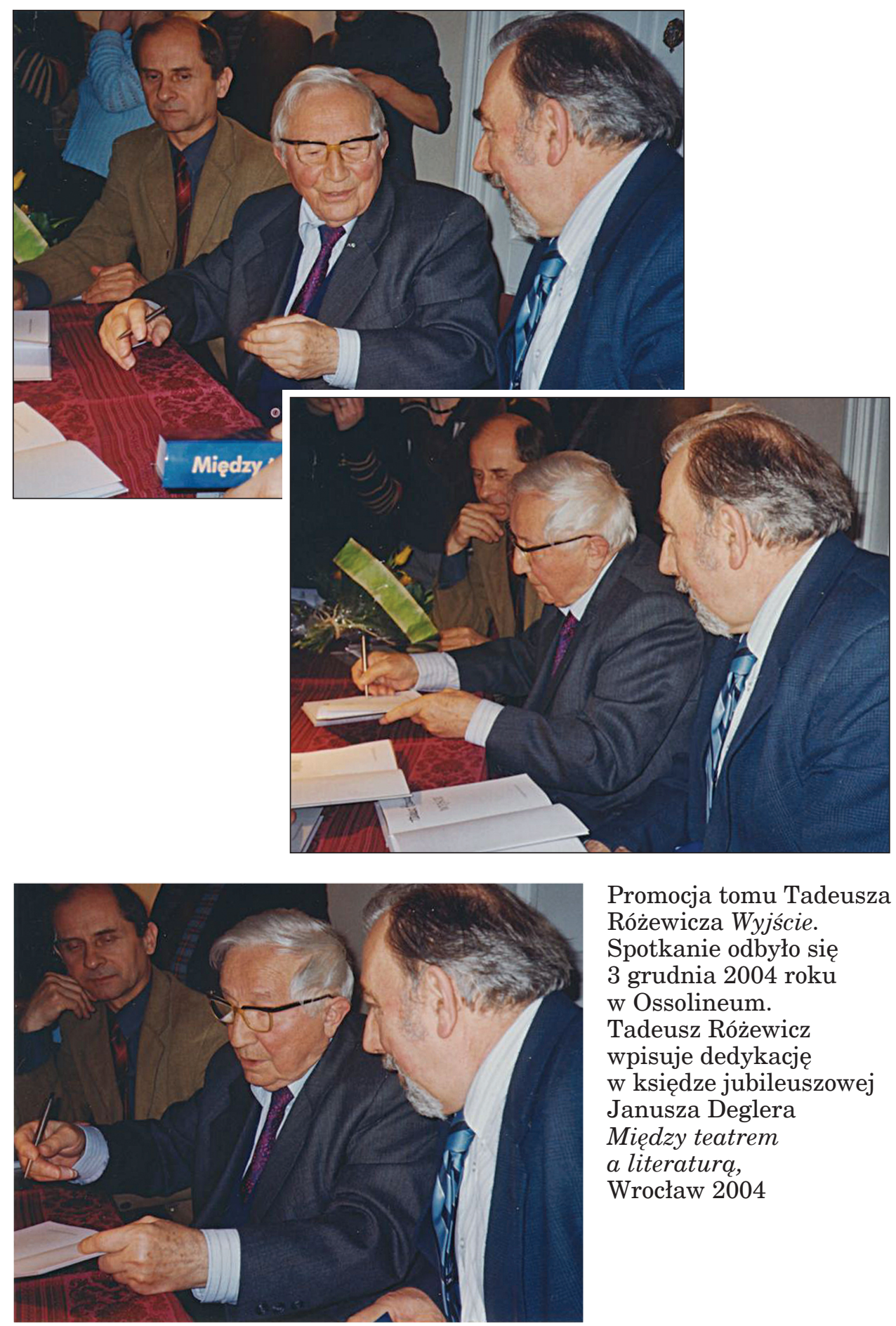

Promocja tomu Tadeusza Różewicza Wyjście.

Spotkanie odbyło się 3 grudnia 2004 roku w Ossolineum. Tadeusz Różewicz wpisuje dedykację w księdze jubileuszowej Janusza Deglera Między teatrem a literatura, Wrocław 2004 

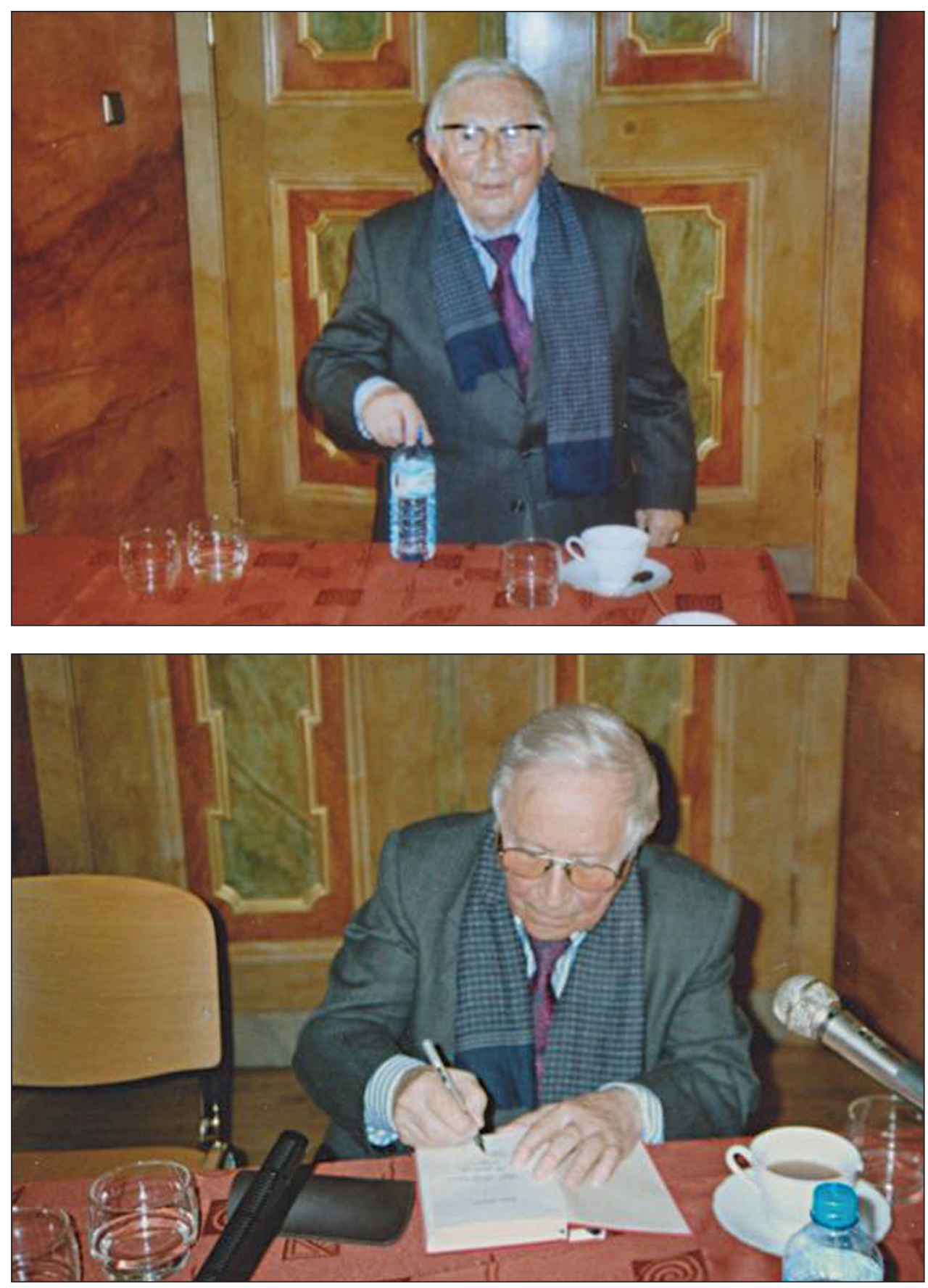

Spotkanie Tadeusza Różewicza ze studentami polonistyki Uniwersytetu Wrocławskiego (marzec 2006). Fot. Janusz Degler 


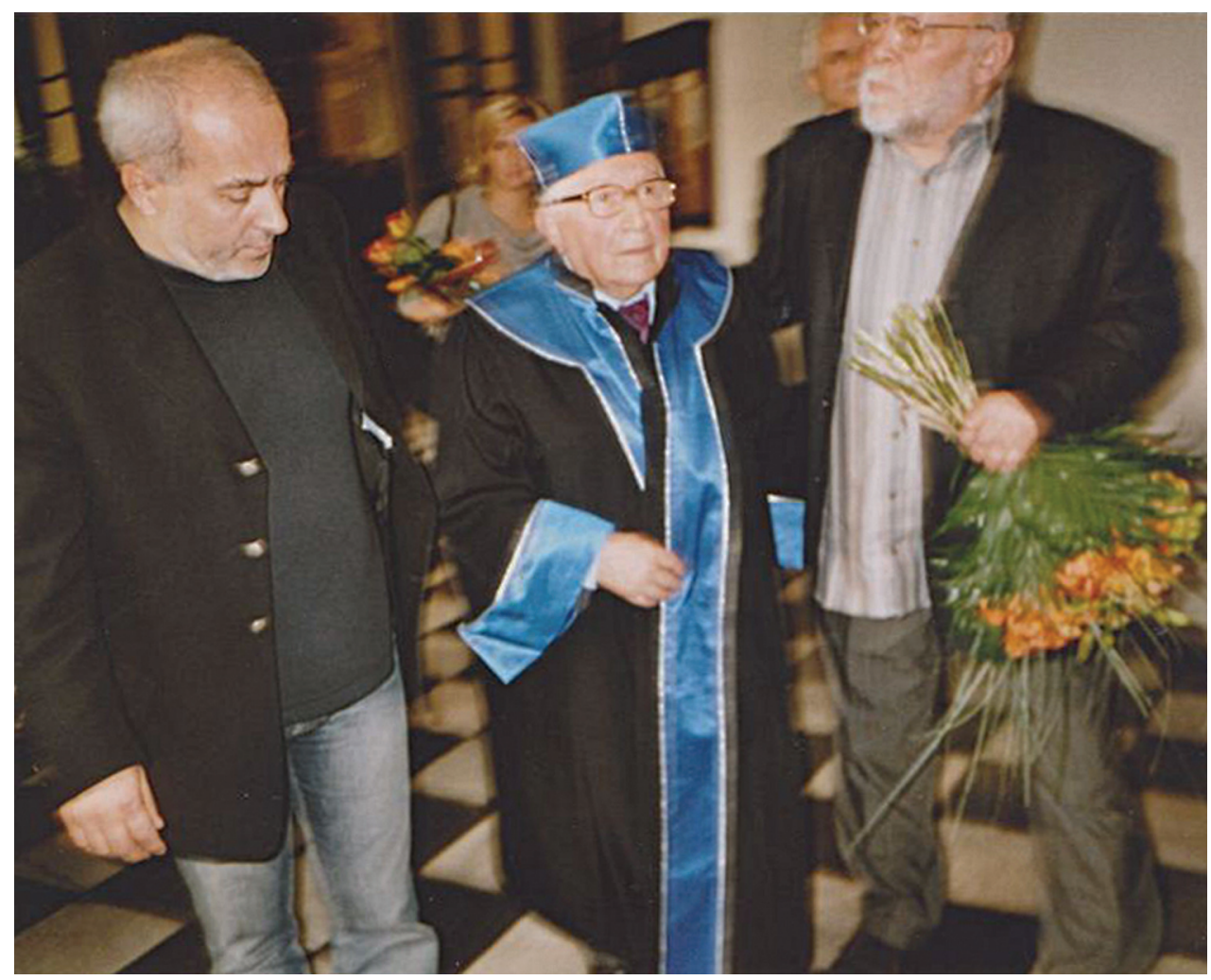

Tadeusz Różewicz po uroczystości nadania tytułu doktora honoris causa Akademii Sztuk Pięknych we Wrocławiu.

Uroczystość odbyła się 8 października 2007 roku.

$\mathrm{Na}$ zdjęciu także Lambros Ziotas i Eugeniusz Get-Stankiewicz. Fot. Janusz Degler 


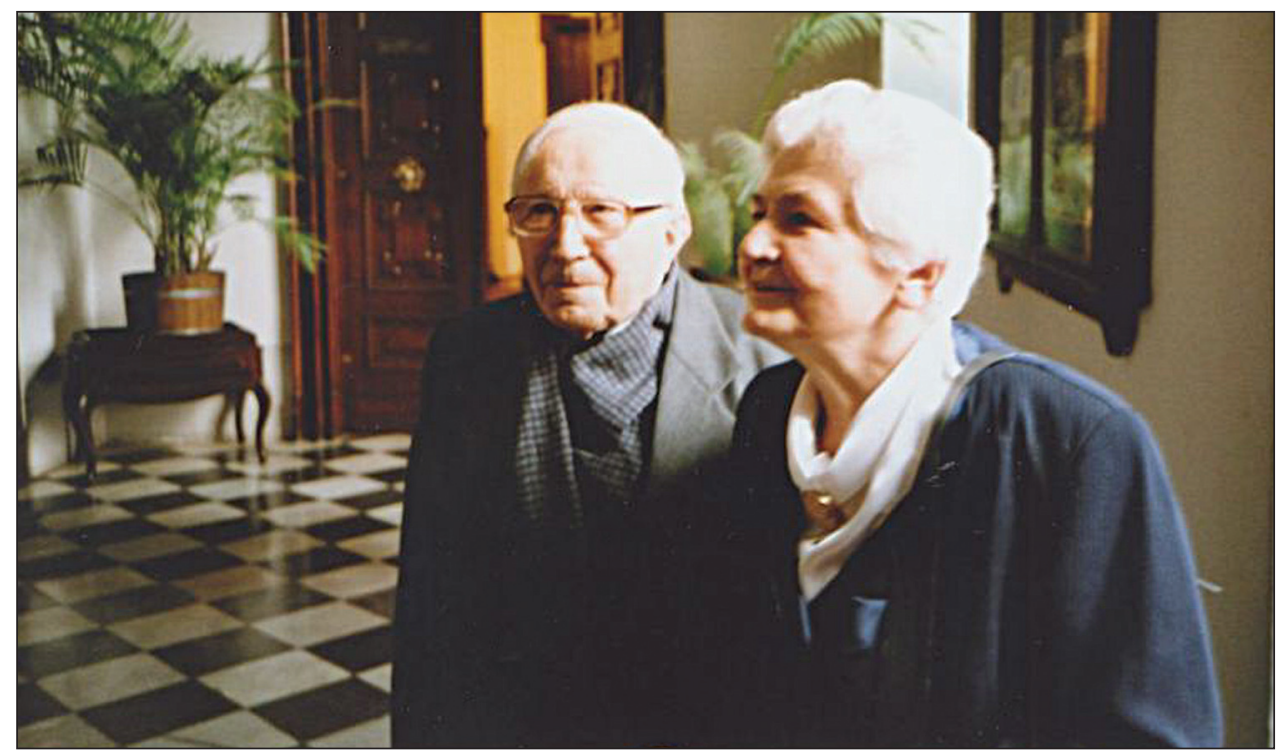

Tadeusz Różewicz z żoną Wiesławą. Fot. Janusz Degler

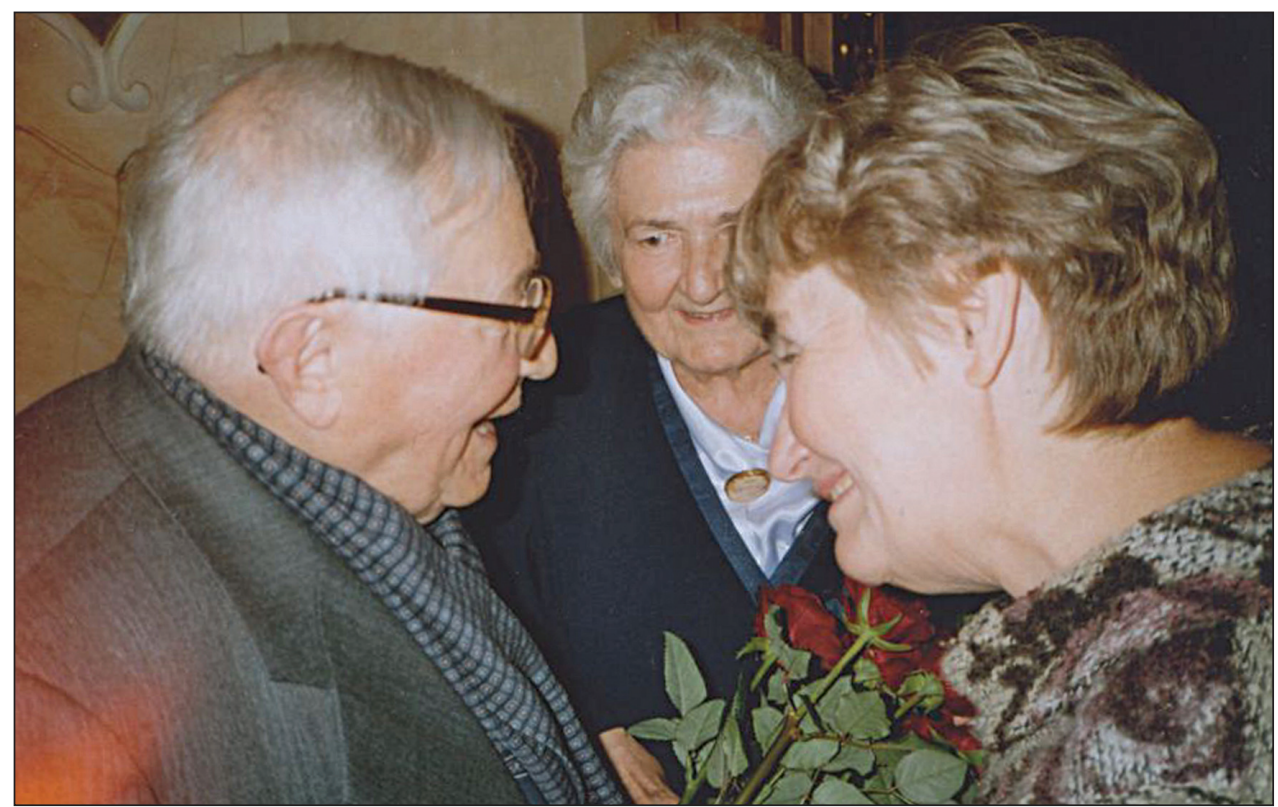

Tadeusz Różewicz, Wiesława Różewiczowa, Ewa Deglerowa.

Po uroczystości nadania tytułu doktora honoris causa Akademii Sztuk Pięknych we Wrocławiu. Fot. Janusz Degler 


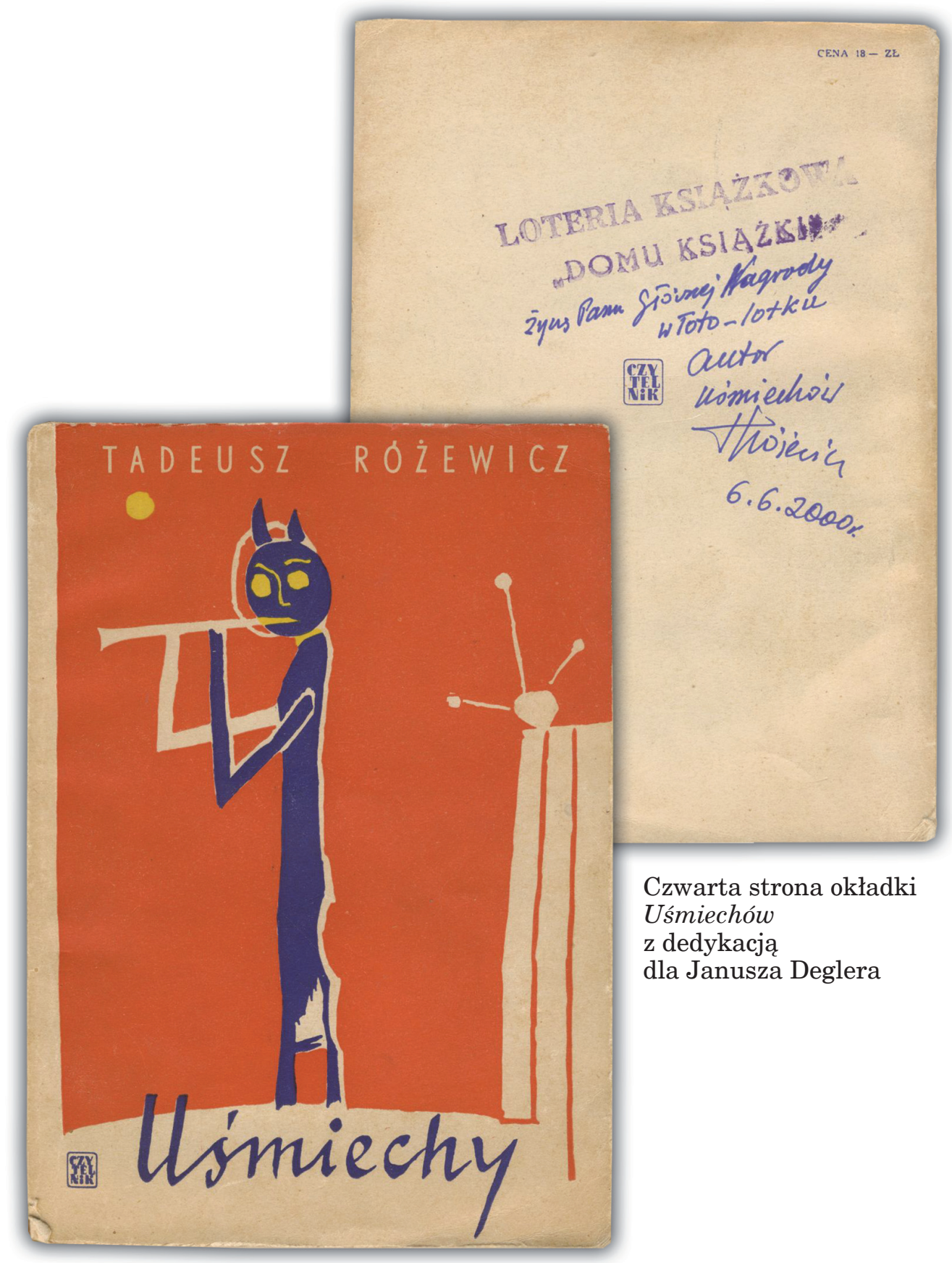

Tadeusz Różewicz, Uśmiechy, ilustrował Jerzy Tchórzewski, Warszawa 1957, wyd. II, Spółdzielnia Wydawnicza Czytelnik. Biblioteka Satyry (okładka) 
Tadeusz Różewicz, Teatr I, Kraków 1988 (dedykacja)

TADEUSZ ROZEWICZ

Teatr

Pamm Jannsawi Deglerowó znakomitemu Grzenooluitions" po Laliryncic Witkacego

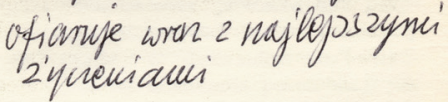

$$
\begin{aligned}
& \text { tAdeun Hóverín } \\
& \text { Wroctaw 30,5, 1990r. }
\end{aligned}
$$

Margines, ale...

Tadeusz

Różewicz,

Margines ale...,

Wrocław 2010

(dedykacja)
Tanie Januszu - jesti Pau tylko zeche to sprerentujs Panue kilka typiscy ksigiet ... (WTganie z "Marginesem.n.)

z wiosennym pordrowieniem dea Powit Ewy

$$
\begin{aligned}
& \text { Hoimin } \\
& \text { 12. III. } 2011 \text {. }
\end{aligned}
$$

